\title{
Hormonal control of carbohydrate metabolism
}

\author{
K. D. BUCHANAN
}

The work which I have done in this field has been mainly in collaboration with Dr J. E. Vance, and I wish to thank him for his assistance in preparing this contribution.

As it is impossible in a single paper to cover completely the vast field of hormonal control of carbohydrate metabolism, this paper will deal only with the pancreatic-enteric group of hormones, ie, insulin, glucagon, gastrin, pancreozymin, secretin, and a glucagon-like immunoreactive material in the gut. This means that the following hormonesgrowth hormone, adrenocorticotrophic hormone, glucocorticoids, catecholamines, oestrogens, and placental lactogen-some of which are of great importance in carbohydrate metabolism, will not be discussed unless their actions in some way impinge upon the hormone under discussion.

\section{ASSAY OF HORMONES}

Undoubtedly the advent of radioimmunoassay techniques for the measurement of polypeptide hormones (Yalow and Berson, 1960) has been a major factor in advancing our knowledge concerning the secretions and actions of hormones. Radioimmunoassay offers a precision and sensitivity far beyond bioassay; for example, Yalow and Berson (1960) quote a sensitivity of $0 \cdot 1 \mu \mathrm{u}$ for insulin, Hazzard, Crockford, Buchanan, Vance, Chen, and Williams (1968) can detect as little as $20 \mu \mu \mathrm{g}$ of glucagon, and Miles and Hales (1968a) report that by a labelled antibody technique they can measure $25 \mu \mu \mathrm{g}$ of growth hormone. Immunoassays are relatively simple to perform, and, by using the popular double-antibody techniques of Morgan and Lazarow (1963) or Hales and Randle (1963), assays incorporating 100 or 200 tubes can easily be performed.

Immunoassays are not without problems, however. The production of suitable antiserum is a prerequisite for a good immunoassay. The larger the hormone, the easier it is to produce antibodies, so that little difficulty has been encountered with insulin and growth hormone. The production of good antisera to ACTH, glucagon, and parathormone, however, presents no easy task. This may be overcome by coupling the hormone to a larger molecule such as albumin before injection into the animal, as has been the case with glucagon (Assan, Rosselin, Drouet, Dolais, and Tchobroutsky, 1965) and gastrin (McGuigan and Trudeau, 1968). Careful and painstaking selection of the correct species of animal is also of importance. For example, Reiss and Canterbury (1968), when looking for an antiserum against parathormone, immunized no fewer than five species of animals of different ages and used several immunization schedules and techniques, but obtained only one suitable antiserum from a cockerel 8 weeks old at the time of the first injection. The almost fortuitous results of immunization are typified by the conflicting findings of Hazzard et al (1968) who reported good production of antibodies to glucagon in guinea pigs but not in rabbits, of Heding (1968), who found the rabbit to be a much more reliable species for the production of glucagon antibodies, and of Assan et al (1965), who found the production of antibodies to be equally good in rabbits and guinea pigs.

Immunoassays, though more specific than bioassays, have their own special problems in this respect. Any material which crossreacts with the antibody will falsely assay as the hormone. It was originally thought that the insulin immunoassay was specific, but it is now realized that levels of circulating immunoreactive insulin may include the separate chains of insulin (Varandani, 1968) or proinsulin (Rubenstein, Cho, and Steiner, 1968). Placental lactogen crossreacts in a growth hormone assay (Greenwood, Hunter, and Klopper, 1964) and a material in the gut crossreacts in the glucagon assay (Samols, Tyler, Megyesi, and Marks, 1966; Unger, Ketterer, and Eisentraut, 1966; Buchanan, Vance, Aoki, and Williams, 1967). In addition, destruction of the labelled hormone by serum (Mirsky, Perisutti, and Davis, 1959), and problems with the second antibody reaction in double antibody techniques (Welborn and Fraser, 1965), add further confusion to the interpretation of results.

\section{GLUCAGON AND INSULIN}

Insulin remains the key hormone in the control of carbohydrate metabolism, but the exact role which it plays is not easy to define in view of the evergrowing list of factors which influence insulin 
secretion (Table I). Several of these factors will now be discussed in some detail. The influence of carbohydrates, proteins, and the enteric hormones will be dealt with 'en bloc' as they are to some extent

\section{TABLE}

SOME FACTORS AFFECTING INSULIN SECRETION

\begin{tabular}{|c|c|c|}
\hline Increase & & Decrease \\
\hline $\begin{array}{l}\text { Monosaccharides } \\
\text { Amino-acids } \\
\text { Ketones } \\
\text { Glucagon } \\
\text { Growth hormone } \\
\text { ACTH } \\
\text { Glucocorticoids } \\
\text { Oestrogens } \\
\text { B-Adrenergic agents }\end{array}$ & $\begin{array}{l}\text { Sulphonylureas } \\
\text { Calcium } \\
\text { Magnesium } \\
\text { Potassium } \\
\text { Cyclic 3',5'-AMP } \\
\text { Vagus stimulation } \\
\text { Secretin } \\
\text { Pancreozymin } \\
\text { Placental lactogen }\end{array}$ & $\begin{array}{l}\text { Catecholamines } \\
\text { Insulin } \\
\text { Starvation } \\
\text { Hypoxia } \\
\text { 2-Deoxyglucose } \\
\text { d-Mannoheptulose } \\
\text { Diazoxide }\end{array}$ \\
\hline
\end{tabular}

interrelated. The question of the hormonal control of metabolic events during starvation will also be considered. First, however, the physiological role of glucagon and its relationship to insulin secretion will be discussed.

\section{PHYSIOLOGICAL ROLE OF GLUCAGON}

The advent of an immunoassay for glucagon (Unger, Eisentraut, McCall, and Madison, 1961) appeared to add only perplexities to the understanding of this hormone. The rise of circulating immunoreactive glucagon (IRG) after oral glucose (Samols, Tyler, Marri, and Marks, 1965b; Lawrence, 1966) seemed to contradict earlier theories that glucagon was the hormone of glucose deprivation (Unger, Eisentraut, McCall, and Madison, 1962) and that its main actions were glycogenolysis (Sokal, Sarcione, and Henderson, 1964) and gluconeogenesis (Sokal, 1966). One of these problems was resolved, however, by the finding that immunoreactive glucagon was detectable in the intestine (Unger et al, 1966; Samols et al, 1966) and that the rise in circulating IRG seen after oral glucose was derived from enteric rather than pancreatic sources (Buchanan et al, 1967; Unger, Ohneda, Valverde, Eisentraut, and Exton, 1968). There has also been some controversy as to whether acute hypoglycaemia stimulates glucagon secretion. Samols and Marks (1967) and Lawrence (1966) have been unable to show this. However Ohneda, Ketterer, Eisentraut, and Unger (1968a) and Buchanan, Vance, Dinstl, and Williams (1969a) used improved methods of hormone assay by incorporating Trasylol in the assay to prevent degradation of the labelled hormone by serum proteases (Hazzard et al, 1968; Eisentraut, Whissen, and Unger, 1968) and have now been able to show rises in pancreatic levels of immunoreactive glucagon during acute hypoglycaemic states and reduction during hyperglycaemia. These findings therefore appear to restore to glucagon its role as a hormone to provide glucose during acute states of hypoglycaemia, but this may not be the only, or even the main, role of this hormone. Further properties of glucagon will be discussed later in relation to hormonal events during starvation and ingestion of food.

The nature of the glucagon-like immunoreactivity in the gut has been the subject of careful study by Unger and his colleagues (Unger et al, 1968; Valverde, Rigopoulou, Exton, Ohneda, Eisentraut, and Unger, 1968). Chromatography has revealed two fractions of glucagon-like immunoreactivity, the molecular weight of one being similar to that of glucagon and of the other about twice that of glucagon. The larger molecule is present in greater amount and does not appear to possess the biological properties of pancreatic glucagon, namely, glycogenolysis, activation of liver phosphorylase, and increase in cyclic $3^{\prime}, 5^{\prime}-\mathrm{AMP}$; it appears, however, to pcssess insulin-stimulating properties, although contamination of the fraction with enteric hormones, particularly pancreozymin, may account for this finding.

\section{HORMONAL CHANGES DURING STARVATION}

Despite recent work on hormone levels during starvation, there remains some controversy as to the changes involved and the contribution of each hormone to the metabolic events. There is agreement that plasma insulin falls during starvation in humans (Cahill, Herrera, Morgan, Soeldner, Steinke, Levy, Reichard, and Kipnis, 1966; Solomon, Ensinck, and Williams, 1968; Vance, Buchanan, and Williams, 1968b), and Cahill et al (1966) implicate an insulinglucose feedback mechanism in the regulation of substrate utilization during fasting. The reports of Unger, Eisentraut, and Madison (1963) and Lawrence (1966), that plasma glucagon rises during starvation, have not been confirmed by Samols and Marks (1967) who showed no change in circulating levels, nor by Vance et al (1968b) who in fact demonstrated a fall in circulating glucagon levels during starvation; moreover Buchanan, Vance, and Williams (1969b) found diminished release of glucagon and insulin from the pancreas of the threeday starved rat. The latter findings suggest that the demand for glucagon as a carbohydrate mobilizer in the starved animal is not as great as in the fed. Because glucagon stimulates insulin secretion (Samols, Marri, and Marks, 1965a; Crockford, Porte, Wood, and Williams, 1966) it is possible that glucagon plays a greater role in the regulation of insulin secretion than in the provision of energy substrates during starvation. Changes in growth hormone secretion during starvation are so erratic 
(Cahill et al, 1966) that interpretation of these data is difficult. Glucocorticoids and the catecholamines may also be of importance during starvation, but a true picture of hormonal changes may not be available until certain problems concerning the assay of some of these hormones, particularly glucagon, growth hormone, and the catecholamines, have been solved. An accurate assessment may only be obtained by a large study monitoring various metabolic events during starvation and incorporating measurement of 24-hour secretion rates of the hormones involved.

RELATIONSHIP BETWEEN GLUCAGON AND INSULIN SECRETION

Samols et al (1965a) and Crockford et al (1966) have shown that glucagon is a potent stimulator of insulin secretion in vivo. Since then numerous workers have confirmed these results in vitro, using pancreas preparations (Turner and McIntyre, 1966; Devrim and Recant, 1966; Vecchio, Luyckx, Zahnd, and Renold, 1966; Malaisse, Malaisse-Lagae, and Mayhew, 1967). That these findings might have physiological significance has been suggested by the results of Ketterer, Eisentraut, and Unger (1967) and Buchanan et al (1969a) who showed that tiny 'physiological' doses of glucagon administered via the portal vein in dogs could increase insulin secretion.

If glucagon has physiological importance in the control of insulin release then one might expect a positive correlation between the release of the two hormones from the pancreatic islet. However, glucose appears to have opposite effects on their release, hypoglycaemia stimulating glucagon release and hyperglycaemia release of insulin (Vance, Buchanan, Challoner, and Williams, 1968a). Adrenalectomy inhibits insulin release from pancreatic islets but stimulates glucagon release (Vance, Kitabchi, Buchanan, and Williams, 1968c). Theophylline and tolbutamide both stimulate insulin release from the islets, but have no effect on glucagon release, and diazoxide and epinephrine inhibit insulin release but have no effect on glucagon release (Vance and Buchanan, 1968; Buchanan, Vance, and Williams, 1969c). However, pancreozymin does stimulate release of both hormones (Unger, Ketterer, Dupré, and Eisentraut, 1967; Buchanan, Vance, Morgan, and Williams, 1968) as do aminoacids (Fajans, Floyd, Knopf, and Conn, 1967). Starvation (vide supra) inhibits the release of both hormones from the pancreatic islets.

It may be that under some conditions the stimulation or inhibition of glucagon release may mediate a similar effect on insulin release. But the numerous exceptions to this rule might in fact indicate the reverse, $i e$, that endogenous glucagon release has no $\stackrel{p}{\rightarrow}$ action on insulin release. Perhaps, as suggested by the findings of Unger et al (1968), it is only the glucagon-like material in the gut which in practice $\frac{\bar{\sigma}}{\overrightarrow{7}}$ promotes insulin secretion. Alternatively, because $\stackrel{\mathbb{D}}{\stackrel{2}{Q}}$

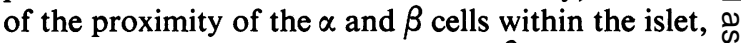
the $\alpha$ cells may act directly on the $\beta$ cells without necessarily affecting the glucagon concentration outside the islet.

HORMONAL EVENTS AFTER THE INGESTION OF FOOD

Since Dupré (1964) showed that an oral glucose load $\stackrel{N}{N}$ is disposed of more rapidly than an intravenous one, and McIntyre, Holdsworth, and Turner (1964) showed that the oral route of glucose administration is associated with a greater rise in circulating insulin i levels than the intravenous route, there has been an 우 enthusiastic search for the enteric factor or factors which might be responsible for this phenomenon. Many factors of enteric origin have been found to promote insulin release, particularly pancreozymin (Meade, Kneubuhler, Schulte, and Barboriak, 1967), and secretin (Dupré, Rojas, White, Unger, and Beck, 1966). Gastrin has slight and transient effects on insulin secretion in dogs (Unger et al, 1967), but is without effect in human subjects (M. T. McKiddie, unpublished observations). Glucagon has insulinstimulating properties (Samols et al, 1965a) and so has the glucagon-like immunoreactivity in the gut (Unger et al, 1968). Even less definable factors in duodenal and jejunal extracts, sometimes called 'incretin', have been found to have insulin-stimulating properties (Turner, 1968). Moreover pancreozymin has been found to stimulate glucagon release (Unger et al, 1967; Buchanan et al, 1968).

It is not yet certain how far the insulinogenic properties of these hormones are of physiological significance. Boyns, Jarret, and Keen (1966) administered acid to stimulate release of endogenous secretin but found no effect on insulin secretion, whereas Dupré, Waddell, Curtis, and Beck (1967) reported that intestinal acidification did result in a release of insulin. The answer may come from Young, Lazarus, and Chisholm (1968) who have developed radioimmunoassays for secretin and pancreozymin. The levels of pancreozymin, secretin (Young et al, 1968), and glucagon-like immunoreactivity from the 0 gut (Buchanan et al, 1967) rise after oral glucose, so 0 that all of these factors may have physiological significance in the disposal of an oral glucose load. $\stackrel{?}{+}$

That enteric factors may be concerned, not only 0 with glucose absorption but also that of other substances given by mouth, is suggested by the work of Dupré, Curtis, Waddell, and Beck (1968); they have 
shown that a more sustained rise in circulating insulin is achieved if amino-acids are infused intraduodenally than if infused intravenously.

It seems logical that the extragastrointestinal hormones, glucagon and insulin, should have some functional overlap with the predominantly gastrointestinal hormones, gastrin, secretin, and pancreozymin. The latter will then be secreted in response to food, not only in order to promote digestion, but also to prepare and aid the endocrine pancreas to deal with the absorbed products of digestion. Although it is clear why insulin should be secreted after a meal, the reason for glucagon secretion is less apparent. Glucagon is secreted in response to amino-acids (Ohneda, Parada, Eisentraut, and Unger, 1968b) and to pancreozymin which is itself stimulated by the ingestion of protein (Wang and Grossman, 1951). Amino-acids also cause insulin release yet without hypoglycaemia (Fajans et al, 1967). It may be that glucagon is secreted following a predominantly protein meal to prevent the hypoglycaemia which might otherwise result from the protein-stimulated insulin secretion.

\section{CONCLUSIONS}

Insulin's key role in carbohydrate metabolism remains unchallenged. However, the recent discovery of proinsulin will lead to reappraisal of the results obtained with insulin immunoassays. Of the other pancreatic-enteric hormones glucagon's function has still not been fully ascertained. The development of an immunoassay for glucagon which can be used to interpret accurately glucagon changes in the peripheral blood of man is awaited. The improvement in sensitivity (Miles and Hales, 1968b), and the use of antibodies which discriminate between gut and pancreatic glucagon (Heding, 1968) appear to offer the greatest promise. Until experience with the immunoassay of pancreozymin, secretin, and gastrin has been accumulated, the role of these hormones in carbohydrate metabolism remains of considerable interest, but as yet physiologically insecure. That further new enteric hormones may emerge remains an intriguing possibility.

\section{SUMMARY}

The role of the pancreatic-enteric group of hormones in carbohydrate metabolism is discussed. It is emphasized that although the immunoassay of polypeptide hormones has rapidly advanced knowledge in this field, certain pitfalls in the technique associated with cross-reacting substances, with degradation of labelled hormone in serum, and with the double-antibody technique have also added confusion to the area. Insulin is the key hormone in carbohydrate metabolism. Glucagon appears to function to provide glucose during acute hypoglycaemic states but its role in more chronic events such as starvation is less clear. Glucagon also stimulates insulin release, and is itself released by pancreozymin and amino-acids; it therefore appears to play a part in the metabolic consequences of food ingestion. A number of enteric hormones, including pancreozymin, secretin, gastrin, and a hormone which reacts immunologically like glucagon but differs in other respects, all have insulin-stimulating properties and therefore appear to be of importance in the utilization of absorbed products of digestion, but their exact physiological role in carbohydrate metabolism is not yet known.

\section{REFERENCES}

Assan, R., Rosselin, G., Drouet, J., Dolais, J., and Tchobroutsky, G. (1965). Lancet, 2, 590.

Boyns, D. R., Jarret, R. J., and Keen, H. (1966). Ibid., 1, 409.

Buchanan, K. D., Vance, J. E., Aoki, T., and Williams, R. H. (1967). Proc. soc. exp. Biol. (N.Y.), 126, 813.

,-- , Dinst 1, K., and Williams, R. H. (1969a). Diabetes, in press. Morgan, A., and Williams, R. H. (1968). Amer. J. Physiol., 215, 1293.

,-- , and Williams, R. H. (1969b). Metabolism, in press.

,$- \ldots$ (1969c). Diabetes, in press.

Cahill, G. F., Jr., Herrera, M. G., Morgan, A. P., Soeldner, J. S., Steinke, J., Levy, P. L., Reichard, G. A., Jr., and Kipnis, D. M. (1966). J. clin. Invest., 45, 1751.

Crockford, P. M., Porte, D., Jr., Wood, F. C., Jr., and Williams, R. H. (1966). Metabolism, 15, 114.

Devrim, S., and Recant, L. (1966). Lancet, 2, 1227.

Dupré, J. (1964). J. Physiol. (Lond.), 175, 58P.

, Curtis, J. D., Waddell, R. W., and Beck, J. C. (1968). Lancet, $2,28$.

—, Rojas, L., White, J. J., Unger, R. H., and Beck, J. C. (1966). Ibid., 2, 26.

Waddell, R. W., Curtis, J. D., and Beck, J. C. (1967). Ibid., 2,611 .

Eisentraut, A. M., Whissen, N., and Unger, R. H. (1968). Amer. J. med. Sci., 255, 137.

Fajans, S. S., Floyd, J. C., Jr., Knopf, R. F., and Conn, J. W. (1967). Recent Prog. Hormone Res., 23, 617.

Greenwood, F. C., Hunter, W. M., and Klopper, A. (1964). Brit. med. J., 1, 22.

Hales, C. N., and Randle, P. J. (1963). Biochem. J., 88, 137.

Hazzard, W. R., Crockford, P. M., Buchanan, K. D., Vance, J. E., Chen, R., and Williams, R. H. (1968). Diabetes, 17, 179.

Heding, L. G. (1968). European Association for the Study of Diabetes, Louvain, Belgium. (Abstr.).

Ketterer, H., Eisentraut, A. M., and Unger, R. H. (1967). Diabetes, $16,283$.

Lawrence, A. M. (1966). Proc, nat. Acad. Sci. (Wash.), 55, 316.

McGuigan, J. E., and Trudeau, W. L. (1968). New Engl. J. Med., 278, 1308.

McIntyre, N., Holdsworth, C. D., and Turner, D. S. (1964). Lancet, $2,20$.

Malaisse, W. J., Malaisse-Lagae, F., and Mayhew, D. (1967). J. clin. Invest., 46, 1724.

Meade, R. C., Kneubuhler, H. A., Schulte, W. J., and Barboriak, J J. (1967). Diabetes, 16, 141.

Miles, L. E. M., and Hales, C. N. (1968a). Lancet, 2, 492. (1968b). Biochem. J., 108, 611 .

Mirsky, I. A., Perisutti, G., and Davis, N. C. (1959). J. clin. Invest., 38, 14.

Morgan, C. R., and Lazarow, A. (1963). Diabetes, 12, 115.

Ohneda, A., Ketterer, H., Eisentraut, A. M., and Unger, R. (1968a). Ibid., 17, 312. (Abstr.) 
—, Parada, E., Eisentraut, A. M., and Unger, R. H. (1968b). Clin. Res., 16, 87. (Abstr.)

Reiss, E., and Canterbury, J. M. (1968). Proc. Soc. exp. Biol. (N.Y.), 128,501 .

Rubenstein, A. H., Cho, S., and Steiner, D. F. (1968). Lancet, 1, 1353. Samols, E., and Marks, V. (1967). Journées Ann. Diabét. Hótel-Dieu, $7,43$.

- Marri, G., and Marks, V. (1965a). Lancet, 2, 415.

—_, Tyler, J., Marri, G., and Marks, V. (1965b). Ibid., 2, 1257.

, Megyesi, C., and Marks, V. (1966). Ibid., 2, 727.

Sokal, J. E. (1966). Endocrinology, 78, 538.

Sarcione, E. J., and Henderson, A. M. (1964). Endocrinology, $74,930$.

Solomon, S. S., Ensinck, J. W., and Williams, R. H. (1968). Metabolism 17,528 .

Turner, D. S. (1968). European Association for the Study of Diabetes, Louvain, Belgium. (Abstr.).

$\longrightarrow$, and McIntyre, N. (1966). Lancet, 1, 351.

Unger, R. H., Eisentraut, A. M., McCall, M. S., and Madison, L. L. (1961). J. clin. Invest., 40, 1280.

$\longrightarrow, \stackrel{-}{-},-$ (1962). Ibid., 41, 682. $\longrightarrow,-$, and Madison, L. L. (1963). Ibid., 42, 1031. , Ketterer, H., Dupré, J., and Eisentraut, A. M. (1967). Ibid., $\overline{\bar{c}}$ 46, 630 .

,$--\frac{}{-}$, and Eisentraut, A. M. (1966). Metabolism, 15, 865.

- Ohneda, A., Valverde, I., Eisentraut, A. M., and Exton, J. (1968). J. clin. Invest., 47, 48.

Valverde, I., Rigopoulou, D., Exton, J., Ohneda, A., Eisentraut, A. M. and Unger, R. H. (1968). Amer. J. med. Sci., 255, 415.

Vance, J. E., and Buchanan, K. D. (1968). Diabetes, 17, 311. (Abstr.). - - , Challoner, D. R., and Williams, R. H. (1968a). Ibid., $17,187$.

,$- \frac{17}{-}$ and Williams, R. H. (1968b). J. Lab. clin. Med., 72, 290. , Kitabchi, A. E., Buchanan, K. D., and Williams, R. H. (1968c) Clin. Res., 16, 131. (Abstr.)

Varandani, P. T. (1968). Diabetes, 17, 547.

Vecchio, D., Luyckx, A., Zahnd, G. R., and Renold, A. E. (1966). Metabolism, 15, 577.

Wang, C. C., and Grossman, M. I. (1951). Amer. J. Physiol., 164, 527.

Welborn, T. A. and Fraser, T. R. (1965). Diabetologia, 1, 211.

Yalow, R. S., and Berson, S. A. (1960). J. clin. Invest., 39, 1157.

Young, J. D., Lazarus, L., and Chisholm, D. J. (1968). Lancet, 2, 914. 